\title{
BONE MORPHOMETRIC PARAMETERS OF THE TIBIA AND FEMUR OF INDIGENOUS AND BROILER CHICKENS REARED INTENSIVELY
}

\author{
MABELEBELE, M. $^{{ }^{*}}$ - NORRIS, D. $^{2}-$ SIWENDU, N. A. ${ }^{3}-$ NG$^{\prime}$ AMBI, J. W. ${ }^{3}-$ \\ ALABI, O. J. ${ }^{3}-$ MBAJIORGU, C. A. ${ }^{1}$ \\ ${ }^{I}$ Department of Agriculture and Animal Health, College of Agriculture and Environmental \\ Science, University of South Africa, Florida Science Campus, South Africa \\ ${ }^{2}$ Research, Development and Innovation, Botswana International University of Science and \\ Technology, Palapye, Botswana \\ ${ }^{3}$ Department of Animal Science, School of Agricultural and Environmental Sciences, University \\ of Limpopo, Polokwane, South Africa \\ *Corresponding author \\ e-mail: mabelebelem@gmail.com; address: University of South Africa, Cnr Christiaan de Wet \\ $R d \&$ Pioneer Ave 1724 Florida Park, Roodepoort, Gauteng, South Africa \\ (Received 22 $2^{\text {nd }}$ Mar 2017; accepted $1^{\text {st }}$ Aug 2017)
}

\begin{abstract}
Good structure and function of skeletal system are among the important factors in poultry management. Therefore, understanding the bone parameters of chickens is of paramount importance as they indicate the basic supportive, locomotive and protective functions. The aim of this study was to determine the bone measurements of Ross 308 broiler and Venda chickens aged 90 days. A 2 (breed) $\times 2$ (sex) factorial arrangement in a completely randomised design was used and replicated four times with 20 birds per replicate. A total of 80 Ross 308 broilers and Venda chickens (20 males, 20 females of each breed) were sacrificed to measure the carcass, tibia, femur and fibula characteristics. A digital calliper and electronic scale were used to measure the length, diameter and weight of the bones. Ash contents of the bones were determined. Tibiotarsal, seedor and robusticity indices of the tibia and femur bones were measured. Tibia and femur lengths and widths were shorter in Venda chickens than those of Ross 308 broiler chickens. Ash contents of tibia and femur diaphysis and epiphysis of male and female Ross 308 broiler and Venda chickens varied significantly between the two breeds. Tibia and femur Seedor index were higher in males and females of Ross 308 broiler than Venda chickens. Diaphysis and medullary canal diameter were higher in Ross 308 broiler chickens than Venda chickens. The tibiotarsal index was lower for Ross 308 broiler than Venda chickens. Sex and breed affected the bone length, weight and width of Ross 308 broiler and Venda chickens at 90 days of age.
\end{abstract}

Keywords: tibiotarsal index, robusticity, length, ash, seedor index

\section{Introduction}

A fast growing broiler chicken is characterised by higher body weight gain, its skeleton (mainly femur and tibia bones) plays a major role as the supporting structure for its body weight (Applegate and Lilburn, 2002). Proper structure and function of skeletal system are among the important factors in animal management; information on bone morphometric will address this factor. According to Warris (2010), in the life cycle of animals, animal tissue development follows a precise order, the first being maturation of the nervous tissue followed by bone then muscle and lastly fat. Previous studies of Buckner et al. (1959) reported a relationship between body weight and various aspects of the tibia and femur bones in male and female New Hampshire chickens. Regression studies of their data designated that more than $98 \%$ of the 
differences in tibia and femur length were a function of the body weight. Itoh and Hatano (1964) who specified that changes in femur ash and mineralisation were a reflective of the total skeletal mineralisation supported this. Study has shown that about 70 to $80 \%$ of bone mass is determined genetically, while 20 to $30 \%$ can be attributed to external factors in which management and diet are the most important factors (Eastell and Lambert, 2002). These factors also have significant effect on bone mineralization (Huyghebaert, 1997). Apart from the metabolic side-products of digestion and compounds synthesised in the intestine, vitamins, minerals or any other nutrient deficiency or excess are also among the important nutritional factors that may influence bone morphometric changes.

Commercial or intensive production systems (broiler chickens production system) are associated with temperature, photoperiod and light intensity controlled conditions, high energy diets, high plane of nutrition and high feed efficiency rates which encourage rapid growth and the early onset of the fattening phase (Lawrie and Ledward, 2006). Extensive production systems (Venda chicken production system), however, would be exposed to fluctuating temperatures and increased exercise on the forage area (Fanatico et al., 2005). Thus, it would be expected that the animals from the intensive production system would reach maturity at an earlier age and would produce heavier slaughter weight and carcasses with more fat if slaughtered at the same age as the free range animals. Castellini et al. (2002) reported lower growth rates and carcass weights of extensive birds compared to intensive birds. However, studies on morphology of the tibia and femur bones in indigenous chickens have not yet been reported. The densitometric and geometric parameters of the internal structures of the bones are of paramount importance as they indicate the basic supportive, locomotive and protective functions by the chickens (Charuta, 2013a). Bone mineral density in chickens is imperative as it helps to better understand and evaluate the process of bone mineral deposition (Louzada, 1994). Therefore, the objective of this study was to determine the bone characteristics of broiler and indigenous chickens aged 90 days.

\section{Materials and methods}

The University of Limpopo Animal Ethics Committee for the care and use of animals approved animal handling procedures for this experiment for scientific purposes with the approval number TREC/12/2014. The study was conducted at the University of Limpopo Experimental Farm, South Africa. The farm is situated $10 \mathrm{~km}$ North-west of the Turfloop campus of the University of Limpopo. The ambient temperature around the area is above $30^{\circ} \mathrm{C}$ during summer and below $25^{\circ} \mathrm{C}$ in winter. The farm lies at latitude $27.55 \mathrm{~S}$ and longitude $24.77 \mathrm{E}$ and receives a mean annual rainfall of less than $400 \mathrm{~mm}$. A total of 80-day-old broiler and indigenous chickens acquired from the University of Limpopo Experimental farm were used in this research. A 2 (breed) $\times 2$ (sex) factorial arrangement in a completely randomised design was used and replicated four times with 20 birds per treatment. The chickens were raised under intensive system and provided with light; feed and water were offered ad libitum for the entire period of the experiment (90 days).

A total of 40 birds were slaughtered by cervical dislocation as recommended by the University of Limpopo Animal Science Ethics Committee. A total of 40 tibiotarsal and femoral bones from Ross 308 broiler and indigenous chickens (Ross 308 and Venda) (20 males and 20 females) were obtained and cleaned of the muscles by boiling them in 
deionized water for 10 minutes. For morphometric analysis, the two types of bones from each breed and sex were weighed $(\mathrm{g})$ with a precision scale (RADWAG, Model PS $750 / \mathrm{C} / 2$ ). The length and width of the bones were determined using a measuring tape and a digital calliper (OMNI-TECH, SHA120). Tibia length was measured from the proximal end to the distal end and the width at the medial diaphysis. The widths of the proximal and distal tibia epiphyses were also measured. Femur length was measured from the proximal end of the shaft to lateral condyle and the width at the medial diaphysis (Zhang and Coon, 1997).

Geometric parameters (Tibiotarsal index, Seedor index and robusticity index) of the bones were determined and the thickness of the medial and lateral walls was measured at the midpoint mark using a dial caliper. Medullary canal diameter was calculated by subtracting the thicknesses of the medial and lateral walls from the diameter at the diaphysis while bone weight/length index also known as the Seedor index was obtained by dividing the tibia weight by its length (Seedor et al., 1991). The tibiotarsal and the robusticity indexes were determined using the following formulas (Reisenfeld, 1972), respectively:

$$
\begin{gathered}
\text { Tibiotarsal index }=\text { diaphysis diameter }- \text { medullary canal } \frac{\text { diameter }}{\text { diaphysis }} \text { diameter } \times 100 \\
\text { Robusticity index }=\text { bone length/cube root of bone weight }
\end{gathered}
$$

The cleaned bones were taken to Polokwane Veterinary Clinic for X-rays analysis. Bones were oven-dried at $105^{\circ} \mathrm{C}$ for $24 \mathrm{~h}$, ashed in a muffle furnace at $600^{\circ} \mathrm{C}$ for $6 \mathrm{~h}$, and ashed at $600^{\circ} \mathrm{C}$ overnight, cooled in a desiccator, and weighed. The samples were then ashed in a muffle furnace at $600^{\circ} \mathrm{C}$ for $24 \mathrm{~h}$ in crucibles (AOAC, 2000). All data was analysed using the General Linear Model procedure of the statistical analysis of systems (SAS, 2008). Analysis of variance was performed and the Duncan's Multiple Range tests were used for mean separation. The level of significance was set at P-value $\leq 0.05$. Polynomials of the tibia and femur weights, lengths and widths as a function of the body weight were determined using the PROC REG procedure of statistical analysis of systems (SAS, 2008).

\section{Results}

The bone traits of male and female Ross 308 broiler and indigenous Venda chickens are presented in Table 1 and Figure 1. Tibia, femur and fibula lengths were longer $(\mathrm{P}<0.05)$ for female Ross 308 broiler than the female Venda chickens. Similarly, male Ross 308 broiler had longer $(\mathrm{P}<0.05)$ tibia and femur bones than male Venda chickens. However, the fibula bones were similar $(\mathrm{P}>0.05)$ for male Ross 308 broiler and Venda chickens. The tibia and femur weights were heavier $(\mathrm{P}<0.05)$ for both male and female Ross 308 broiler compared to those of Venda chickens. Similar fibula weights $(\mathrm{P}>0.05)$ were observed for both male and female Ross 308 broiler and Venda chickens. The width of the tibia and femur followed the same trend as observed for the length and weight, with male and female Ross 308 broiler chickens having wider $(\mathrm{P}<0.05)$ bones than those observed in male and female Venda chickens. The fibula bone width, however, was not influenced $(\mathrm{P}>0.05)$ by either sex or breed of the chickens. 

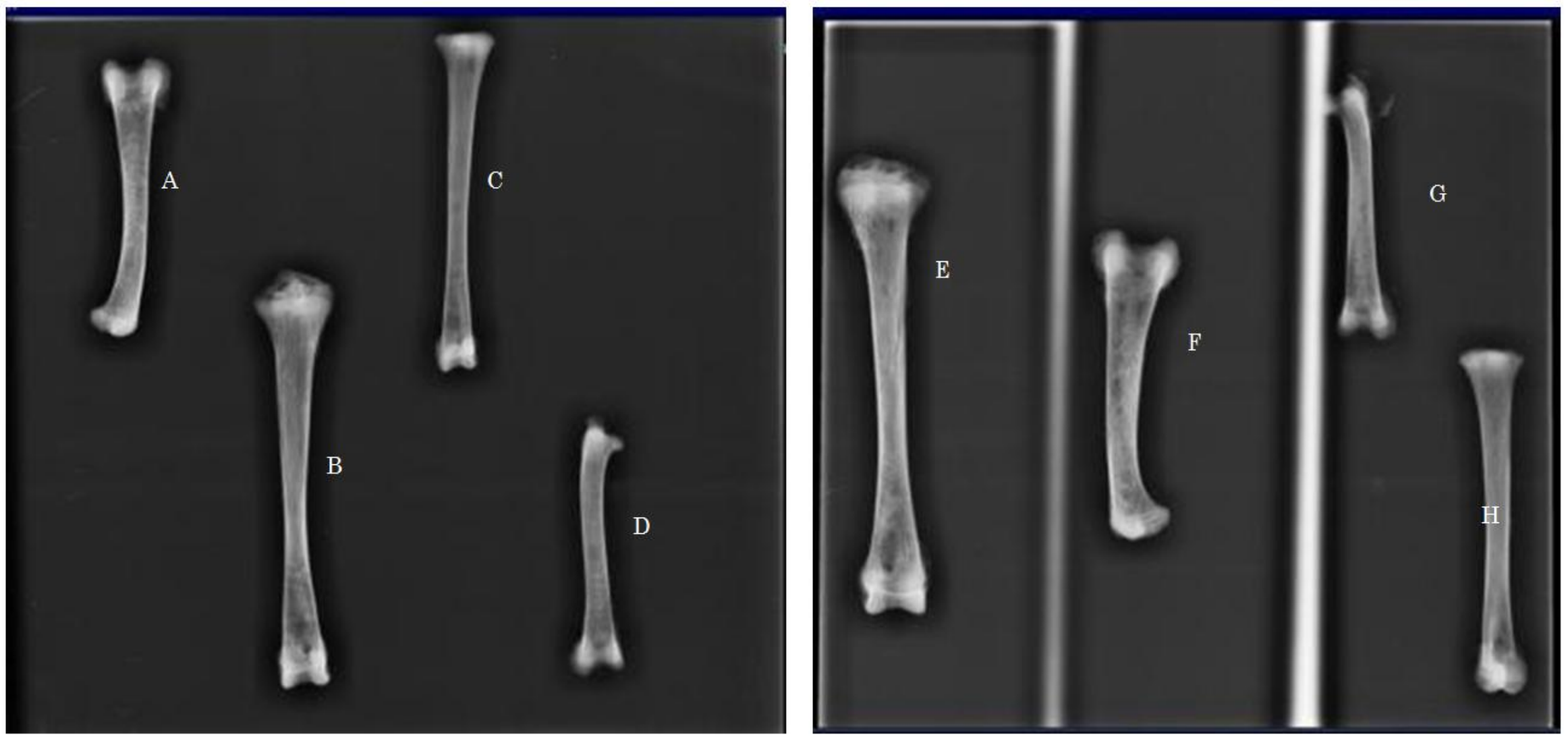

Figure 1. A) Femur for male Ross 308 broiler chicken. B) Tibia for male Ross 308 broiler chicken. C) Tibia for male Venda chicken. D) Femur for male Venda chicken. E) Tibia for female Ross 308 broiler chicken. F) Femur for female Ross 308 broiler chicken. G) Femur for female Venda chicken. H) Tibia for female Venda chicken. 
Table 1. Bone length $(\mathrm{mm})$, weight $(\mathrm{g})$ and width $(\mathrm{mm})$ of female and male Ross 308 broiler and indigenous Venda chickens

\begin{tabular}{|c|c|c|c|c|}
\hline \multirow{2}{*}{ Variable } & \multicolumn{4}{|c|}{ Breed } \\
\hline & Sex & Ross 308 & Venda & SEM \\
\hline \multirow{2}{*}{ Tibia length } & Female & $126.06^{\mathrm{a}}$ & $115.52^{b}$ & 6.298 \\
\hline & Male & $144.90^{\mathrm{a}}$ & $117.41^{\mathrm{b}}$ & 2.81 \\
\hline \multirow{2}{*}{ Femur length } & Female & $92.38^{\mathrm{a}}$ & $82.44^{\mathrm{b}}$ & 5.872 \\
\hline & Male & $96.89^{\mathrm{a}}$ & $85.84^{\mathrm{b}}$ & 1.432 \\
\hline \multirow{2}{*}{ Fibula length } & Female & $89.70^{\mathrm{a}}$ & $80.75^{\mathrm{b}}$ & 1.450 \\
\hline & Male & 86.42 & 80.87 & 5.904 \\
\hline \multirow{2}{*}{ Tibia weight } & Female & $25.58^{\mathrm{a}}$ & $13.50^{\mathrm{b}}$ & 1.085 \\
\hline & Male & $36.91^{\mathrm{a}}$ & $16.69^{\mathrm{b}}$ & 1.283 \\
\hline \multirow{2}{*}{ Femur weight } & Female & $18.08^{\mathrm{a}}$ & $11.14^{\mathrm{b}}$ & 0.648 \\
\hline & Male & $24.30^{\mathrm{a}}$ & $14.75^{\mathrm{b}}$ & 1.184 \\
\hline \multirow{2}{*}{ Fibula weight } & Female & 2.10 & 1.64 & 0.183 \\
\hline & Male & 2.86 & 1.86 & 0.319 \\
\hline \multirow{2}{*}{ Body weight } & Female & $1862.01^{\mathrm{a}}$ & $750.17^{\mathrm{b}}$ & 37.538 \\
\hline & Male & $2349.60^{\mathrm{a}}$ & $890.20^{\mathrm{b}}$ & 93.757 \\
\hline \multirow{2}{*}{ Tibia width } & Female & $8.79^{\mathrm{a}}$ & $6.74^{\mathrm{b}}$ & 0.295 \\
\hline & Male & $10.19^{\mathrm{a}}$ & $7.40^{\mathrm{b}}$ & 0.445 \\
\hline \multirow{2}{*}{ Femur width } & Female & $9.42^{\mathrm{a}}$ & $7.83^{\mathrm{b}}$ & 0.305 \\
\hline & Male & $10.85^{\mathrm{a}}$ & $8.70^{\mathrm{b}}$ & 0.206 \\
\hline \multirow{2}{*}{ Fibula width } & Female & 2.82 & 2.36 & 0.382 \\
\hline & Male & 3.30 & 2.39 & 0.293 \\
\hline
\end{tabular}

SEM: Standard error of the mean

${ }_{a, b}$ Means within the same row with different letters are significantly different $(\mathrm{P}<0.05)$

The polynomial regression of tibia and femur length and weight of Ross 308 broiler and indigenous Venda chickens as a function of carcass weight are presented in Figure 2. Calculated as a function of carcass weight, $97 \%$ of tibia length and $94 \%$ of femur length in Ross 308 broiler chickens are a result of changes in body weight (Figure 2A). However, compared to Venda chickens when polynomial functions were calculated, lower values of $89 \%$ of tibia length and $37 \%$ of femur length were because of variations in carcass weights (Figure $2 C$ ). When bone weight was determined as a function of carcass weight, $95 \%$ and $88 \%$ of tibia weight of Ross 308 broiler and Venda chickens were observed, respectively. Similar values of $93 \%$ and $91 \%$ of femur weight of Ross 308 broiler and Venda chickens were observed as function of carcass weight, respectively (Figures $2 B$ and $2 D$ ). 

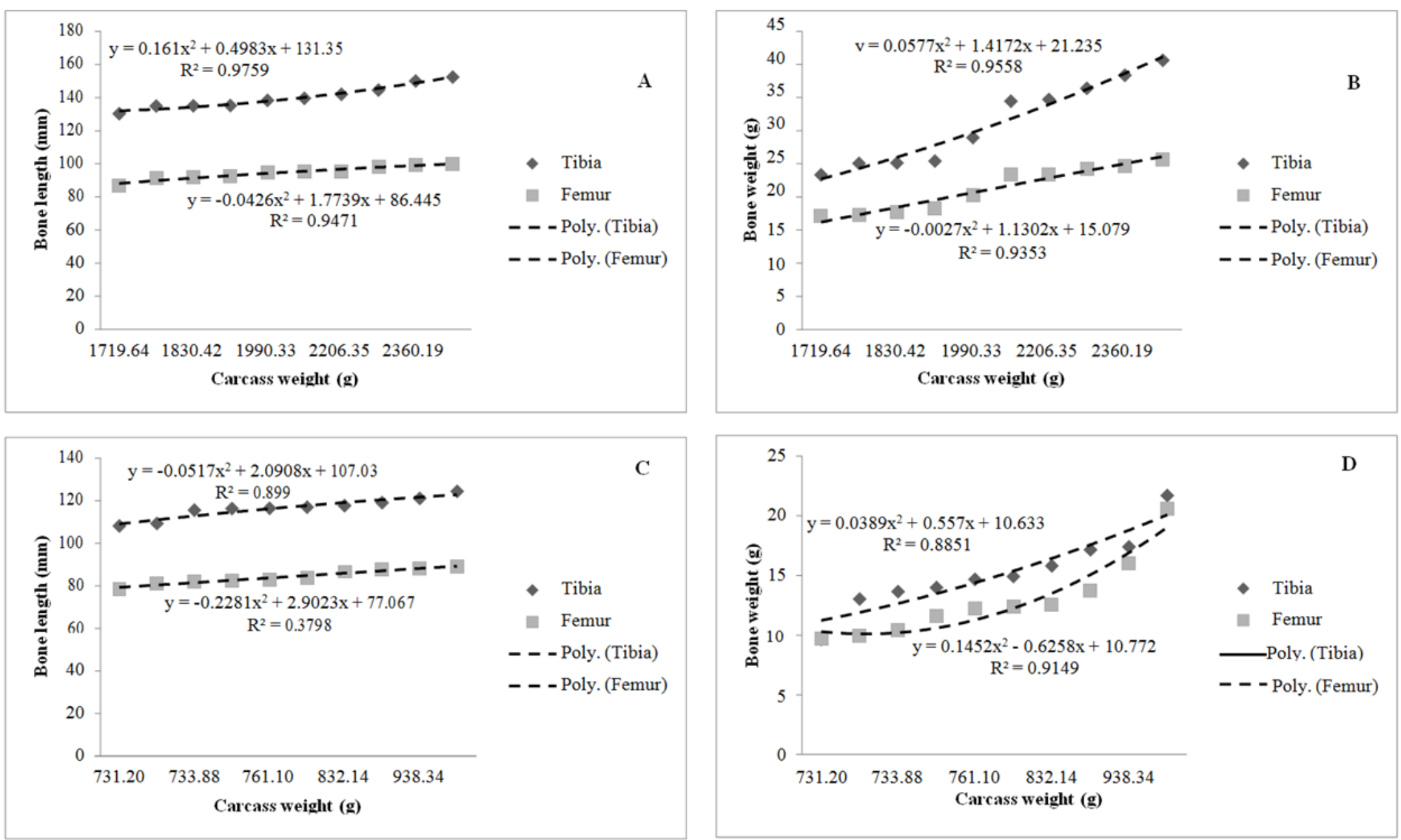

Figure 2. A) Regression of Ross 308 broiler tibia and femur length ( $\mathrm{mm}$ ) on carcass weight. B) Regression of Ross 308 broiler tibia and femur weight $(\mathrm{g})$ on carcass weight. $C)$ Regression of indigenous Venda chickens' tibia and femur length (mm) on carcass weight. D) Regression of indigenous Venda chickens' tibia and femur weight ( $g$ ) on carcass weight.

APPLIED ECOLOGY AND ENVIRONMENTAL RESEARCH 15(4):1387-1398.

http://www.aloki.hu • ISSN 15891623 (Print) • ISSN 17850037 (Online)

DOI: http://dx.doi.org/10.15666/aeer/1504_13871398

(c) 2017, ALÖKI Kft., Budapest, Hungary 
Tibia and femur geometric parameters of male and female Ross 308 broiler and indigenous Venda chickens are shown in Table 2. Tibia Seedor index was higher $(\mathrm{P}<0.05)$ in males and females of Ross 308 broiler than their counterparts Venda chickens. The femur Seedor index also followed the similar trend as tibia Seedor index with higher values $(\mathrm{P}<0.05)$ reported for male and female of Ross 308 broiler than Venda chickens. No differences $(\mathrm{P}>0.05)$ were observed for tibia and femur robusticity indices of male and female Ross 308 broiler and Venda chickens. The tibia diaphysis and medullary canal diameter of male and female Ross 308 broiler chickens were higher $(\mathrm{P}<0.05)$ than those in Venda chickens. The tibiotarsal index was higher $(\mathrm{P}<0.05)$ for male and female Venda chickens than for Ross 308 broiler chickens.

Table 2. Bone geometric analysis of male and female Ross 308 broiler and indigenous Venda chickens

\begin{tabular}{c|c|c|c|c}
\hline \multirow{2}{*}{ Variables } & \multicolumn{3}{|c}{ Breed } \\
\cline { 2 - 5 } & Sex & $\begin{array}{c}\text { Ross } \\
\mathbf{3 0 8}\end{array}$ & Venda & SEM \\
\hline \multirow{2}{*}{ Tibia Seedor Index $(\mathrm{mg} / \mathrm{mm})$} & Female & $207.81^{\mathrm{a}}$ & $116.31^{\mathrm{b}}$ & 14.765 \\
& Male & $254.84^{\mathrm{a}}$ & $141.49^{\mathrm{b}}$ & 7.953 \\
Femur Seedor Index $(\mathrm{mg} / \mathrm{mm})$ & Female & $196.58^{\mathrm{a}}$ & $135.68^{\mathrm{b}}$ & 9.810 \\
& Male & $251.05^{\mathrm{a}}$ & $175.57^{\mathrm{b}}$ & 15.191 \\
Tibia Robusticity Index & Female & 4.28 & 4.88 & 0.219 \\
& Male & 4.35 & 4.61 & 0.064 \\
Femur Robusticity Index & Female & 3.51 & 3.70 & 0.104 \\
Diaphysis Diameter (mm) & Male & 3.34 & 3.53 & 0.109 \\
& Female & $9.62^{\mathrm{a}}$ & $7.80^{\mathrm{b}}$ & 0.420 \\
Medullary canal diameter (mm) & Male & $10.38^{\mathrm{a}}$ & $8.63^{\mathrm{b}}$ & 0.398 \\
& Female & $6.93^{\mathrm{a}}$ & $5.47^{\mathrm{b}}$ & 0.162 \\
Tibiotarsal Index & Male & $7.31^{\mathrm{a}}$ & $5.99^{\mathrm{b}}$ & 0.344 \\
& Female & $27.37^{\mathrm{b}}$ & $33.50^{\mathrm{a}}$ & 0.469 \\
& Male & $25.00^{\mathrm{b}}$ & $32.35^{\mathrm{a}}$ & 0.938 \\
\hline
\end{tabular}

SEM: Standard error of the mean

${ }^{a, b}$ Means within the same row with different letters are significantly different $(\mathrm{P}<0.05)$

Ash contents of tibia and femur diaphysis and epiphysis of Ross 308 broiler and indigenous Venda chickens are presented in Figures 3. Ash content of the femur epiphysis was higher $(\mathrm{P}<0.05)$ in Venda male than the male of Ross 308 broiler chickens. However, female Ross 308 broiler and Venda female chickens exhibited similar $(\mathrm{P}>0.05)$ femur epiphysis ash contents. Tibia epiphysis ash contents were not different $(\mathrm{P}>0.05)$ between males and females of Ross 308 broiler and Venda chickens. Tibia diaphysis ash content was higher $(\mathrm{P}<0.05)$ in Venda males than Ross 308 broiler males. Similar tibia diaphysis ash content $(\mathrm{P}>0.05)$ were observed in the females of Venda and Ross 308 broiler chickens. A higher $(\mathrm{P}<0.05)$ femur diaphysis ash content was observed in Venda females than males of Ross 308 broiler and Venda chickens. Ross 308 broiler male had lower $(\mathrm{P}>0.05)$ femur diaphysis ash content. 

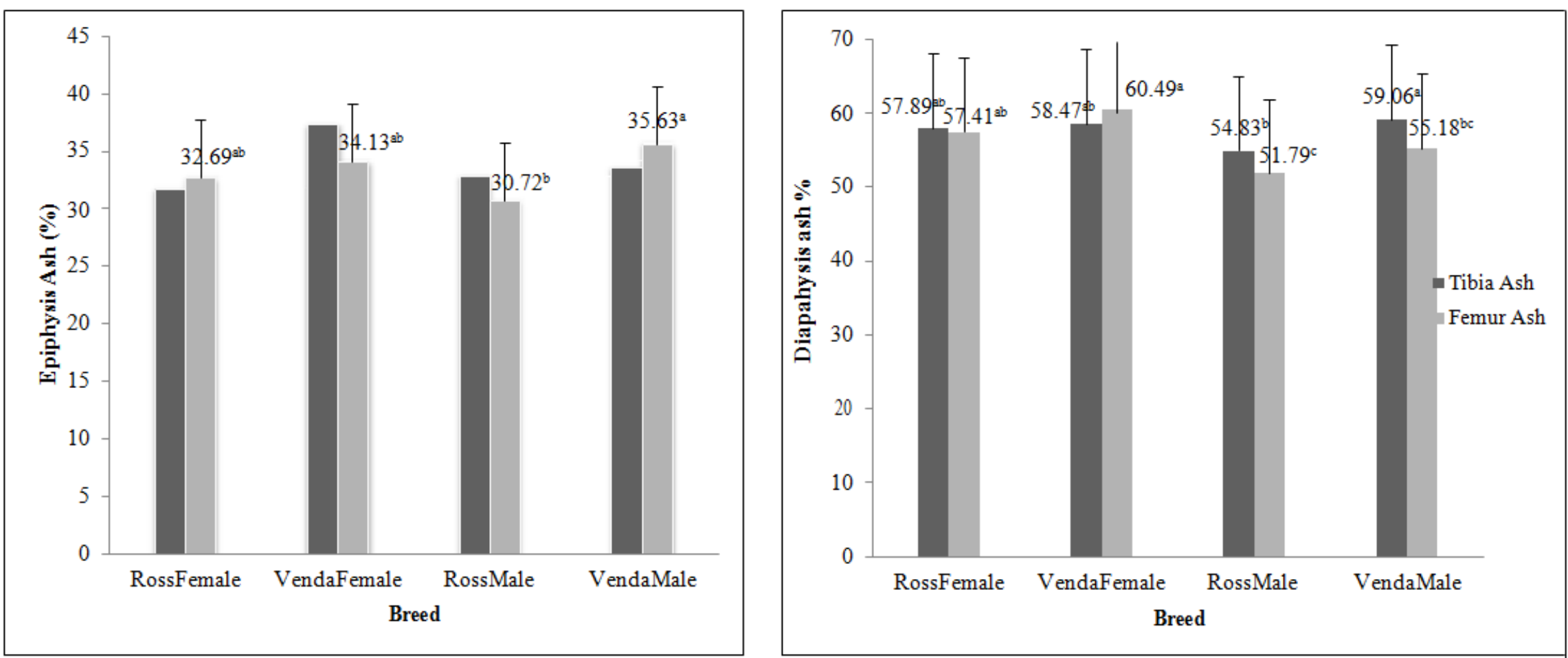

Figure 3. Tibia and Femur Epiphysis and Diaphysis Ash (\%) of Female and Male Ross 308 and Indigenous Venda aged 90 days.

${ }^{a, b, c}$ Means within the same column with different letters are significantly different $(P<0.05)$. 


\section{Discussion}

In recent decades, selection pressure has been applied in poultry for fast growth and high meat production (Breugelmans et al., 2007; Kirkwood et al., 1989). This, in turn, puts pressure on the skeleton of the bird to support the heavier body weights associated with broiler chickens (Breugelmans et al., 2007). The femur bone length in the current study at 90 days for male and female Ross 308 broiler were 96.89 and $92.38 \mathrm{~mm}$, respectively, whereas for male and female Venda chickens they were 85.44 and 82.44 $\mathrm{mm}$, respectively. The values in the present study were lower than those reported by Breugelmans et al. (2007) who indicated that at 98 days of age Ross 308 broiler chickens had a femoral length of $116 \mathrm{~mm}$, this might be due to age differences. The tibia lengths for Ross 308 broiler were 144.90 for males and $126.06 \mathrm{~mm}$ for females in the current study. This is similar to the previous results obtained by Latimer (1927) reported similar results for broiler chickens to those observed in the current study. The tibia lengths of male and female Venda chickens were 117.4 and $115.5 \mathrm{~mm}$, respectively. These values are lower compared to those of male and female Ross 308 broiler chickens at the same age in the current study. This can be attributed to breed differences. The males in the present study, regardless of the breed, had longer tibia and femur lengths compared to their females. Charuta et al. (2013a) and Rose et al. (1996) who indicated that bone length is related to sexual dimorphism support these results. The lengths of both the tibia and femur of slow growing Venda chickens, irrespective of the sex, were lower compared to those of the fast growing broiler chickens. Therefore, breed had an effect on the bone length of chickens.

Calculated as a function of carcass weight, tibia and femur lengths were compared and R-value of $97 \%$ was a result of the variability in carcass weight of Ross 308 broiler chickens; however, only $89 \%$ was recorded for indigenous Venda chickens. Buckner et al. (1950) observed a $>98 \%$ as differences in tibia bone lengths in male and female New Hampshire chickens aged 196 days. The bone weights of chickens breeds used in this study were significantly higher for males than females. This was similar to the findings of Applegate and Lilburn (2002) who observed that sex had an effect on tibia and femur weights. However, slow growing Venda chickens in the current study with lighter body weight had lower tibia and femur weights compared to their counterparts Ross 308 broiler chickens. Although when the polynomial function of tibia and femur weights was calculated, R-value of $88 \%$ for tibia and $91 \%$ for femur are results of variations of the body weight for indigenous Venda chickens. Applegate and Lilburn (2002) and Buckner et al. (1950) observed that $>98 \%$ of the variations in tibia and femur weights are function of the body weight for broiler chickens aged 43 days and New Hampshire chickens aged 23 weeks. Tibia and femur width of the male and female Ross 308 in the current study tended to follow a similar trend as the bone weights and lengths. Increase in bone length would be expected to correlate with the bone width indicating the overall bone size (Van Wyhe et al., 2012) which was the case with Ross 308 broiler chickens in this study. If the bone length continues to grow and increase without the increase in bone width, this could predispose chickens to increased skeletal problems.

Epiphyseal ash content of the femur was higher for Venda male chickens in the current study. The epiphyseal region of the bone is responsible for the linear increase in bone growth and this process amongst others includes mineralization (Van Wyhe et al., 2012; Applegate and Lilburn, 2002). The percentage of ash in this region would be expected to vary according to nutrition and age. These results are supported by Lin et al. 
(2012) indicating that bone ash was higher for Taiwan male chickens at 14 weeks of age. The reasons why both male and female indigenous Venda chickens had higher epiphyseal ash content compared to their counterparts is unclear in the current study. Ash content was higher in the tibia and femur diaphyseal region of male and female indigenous Venda chickens compared to lower percentile values in male and female of Ross 308 broiler chickens. Thorp (1992) compared the ash content at the femur diaphysis with the tibia one and observed that ash content was lower in femur, suggesting that this bone can be a vulnerable point of chickens and can be responsible for long bone abnormalities. Previous studies by Itoh and Hatano (1964); Dilworth and Day (1965) and Moran Junior and Todd (1994) concluded that femur bones in Ross 308 broiler chickens are more sensible to changes in diet than tibia bone.

The Seedor index that is also known as bone weight/bone length index is an indication of bone density (Seedor, 1995; Ameida and Bruno, 2006). Higher bone densities in the current study were observed for male and female Ross 308 broiler chickens than Venda chickens. These higher densities in Ross 308 broiler chickens are an indication of their heavier weight. A low robusticity index is an indication of strong bone structure (Safaeikatouli et al., 2012). Robusticity indexes of both tibia and neither breed nor sex affected femur bones. This was not expected for Venda chickens, as indigenous chickens are known to have stronger bone structure than broiler chickens. Perhaps, the reasons why indigenous chickens in the current study had similar robusticity index with broiler chickens would be the similar rearing systems under which both breeds were reared. Diaphysis and medullary canal diameter of Ross 308 broiler chickens were observed to be higher than in Venda chickens. Tibiotarsal index points out mineralization in the bone, and therefore a higher index indicates higher mineralization level in the bone (Ziaie et al., 2011).

Male and female Venda chickens had higher tibiotarsal index than male and female of Ross 308 broiler chickens. The above findings are supported and confirmed by the higher epiphyseal and diaphyseal ash content of male and female of Venda chickens in the current study. The higher mineralization in male and female Venda chickens is an indication of better bone quality than Ross 308 broiler chickens. Sex and breed affected the bone length, weight and width of Ross 308 broiler and indigenous chickens at 90 days of age. Bone geometry and densitometry analysis varied amongst breed and sex of chickens. Venda chickens had higher epiphyseal and diaphyseal ash content, which was confirmed by the higher tibiotarsal index. On the contrary, Ross 308 broiler chickens had higher femur and tibia Seedor index, which is an indication of denser bones. Although it was expected that indigenous Venda chickens that are hardier would have stronger bone structure than broiler chickens, this was not the case in this study. Perhaps the rearing system could have contributed to similar robusticity indexes that are an indicative of bone strength. This information will have implications when selecting chickens for better bone quality and strength.

\section{Conclusion}

In most of the morphometric parameters measured, both the male and female Ross 308 broiler chickens have superior values than the Venda chickens. However, in the ash contents, the male and female Venda chickens had higher values. Tibia and femur lengths were longer for female Ross 308 broiler than the female Venda chickens. Similarly, the tibia and femur weights were heavier for both male and female Ross 308 
broiler compared to those of Venda chickens. However, fibula weights were similar for both male and female Ross 308 broiler and Venda chickens. The width of the tibia and femur followed the same trend as observed for the length and weight. Tibia and femur Seedor index were higher in males and females of Ross 308 broiler than the Venda chickens. The tibia diaphysis and medullary canal diameter of male and female Ross 308 broiler chickens were higher than those in Venda chickens. However, the tibiotarsal index was higher for male and female Venda chickens than for Ross 308 broiler chickens. Ash contents of the femur epiphysis and femur and tibia diaphysis were higher in Venda male than the male of Ross 308 broiler chickens. Similarly, tibia diaphysis ash content was higher in Venda males than Ross 308 broiler males. However, tibia and femur epiphysis ash contents were similar in both males and females of Ross 308 broiler and Venda chickens. The tibia diaphysis ash content was also similar in the females of Venda and Ross 308 broiler chickens.

\section{REFERENCES}

[1] Almeida Paz, I. C. L., Bruno, L. D. G. (2006): Bone mineral density: review. - Brazilian Journal of Poultry Science 8: 69-73.

[2] AOAC (Association of Official Analytical Chemists) Official Methods of Analysis. (2000): 17th ed. - AOAC, Arlington, VA.

[3] Applegate, T. J., Lilburn, M. S. (2002): Growth of the femur and tibia of a commercial broiler line. - Poultry Science 81: 1289-1294.

[4] Breugelmans, S., Muylle, S., Cornillie, P., Saunders, J., Simoens, P. (2007): Age determination of poultry: a challenge for customs. - Vlaams diergeneeskunde tijdschrift 76: 423-430.

[5] Buckner, C. D., Fefer, A., Bensinger, W. L., Storb, R., Durie, B. G., Appelbaum, F. R., Petersen, F. B., Weiden, P., Clift, R. A., Sanders, J. E., Sullivan, K. M., Witherspoon, R. P., Hill, R., Martin, P., Thomas, E. D. (1959): Marrow transplantation for malignant plasma cell disorders: summary of the Seattle experience. - European Haematology 43: 186-190.

[6] Buckner, G. D., Insko, W. M., Harms-Henry Jr., A., Faull-Wachs, E. (1950): The comparative rates of growth and calcification of the femur, tibia and metatarsus bones of the male and female New Hampshire chicken having straight keel. - Poultry Science 29: 332-335.

[7] Castellini, C., Mugnai, C, Dal Bosco, A. (2002a): Meat quality of three chicken genotypes reared according to the organic system. - Italian Journal of Food Science 14: 403-414.

[8] Charuta, A. (2013a): Evaluation of densitometric and geometric parameters of the femur in 14-month-old ostriches depending on sex with the use of computed tomography. Bulletin of the Veterinary Institute in Pulawy 57: 287-291.

[9] Dilworth, B. C., Day, E. J. (1965): Effect of varying dietary calcium: phosphorus ratios on tibia and femur composition of the chick. - Poultry Science 44: 1474-1479.

[10] Itoh, H., Hatano, T. (1964): Comparison of calcium metabolism in various bones of growing chicks in varying states of vitamin D supplementation. - Poultry Science 43: 7076.

[11] Kirkwood, J., Kichenside, C., James, W. (1989): Training zoo animals. Proceedings of Animal Training Symposium: A Review and Commentary on Current Practices. Universities Federation for Animal Welfare, Cambridge, UK., 93-99 
[12] Latimer, H. B. (1927): Postnatal growth of the chicken skeleton. - Amimal Journal of Anatomy 40: 1-57.

[13] Lin, C. Y., Hsu, J. C., Wan, T. C. (2012): Effect of Age and Caponization on Blood Parameters and Bone Development of Male Native Chickens in Taiwan. - Asian-Austral Journal of Animal Science 25: 994-1002.

[14] Louzada, M. J. Q. (1994): Otimização da técnica de densitometria óptica em imagens radiográficas de peças ósseas. Estudo in vitro [tese].Campinas. - Universidade Estadual de Campinas Brazil, PhD Dissertation.

[15] Moran, E. T., Jr. Todd, M. C. (1994): Continuous sub marginal phosphorus with broilers and the effect of preslaughter transportation: carcass defects, further-processing yields, and tibia-femur integrity. - Poultry Science 73: 1448-1457.

[16] Reisenfeld, A. (1972): Metatarsal robusticity in bipedal rats. - Am. J. Phys. Anthropology 40: 229-234.

[17] Rose, N., Constantin, P., Leterrier, C. (1996): Sex differences in bone growth of broiler chickens. - Growth Develop Aging 60: 49-59.

[18] Safaeikatouli, M., Boldaji, F., Dastar, B., Hassan, S. (2012): Growth response and tibia bone characteristics in broilers fed diets containing kaolin, bentonite and zeolite. Journal of Animal Feed Science 21: 334-344.

[19] SAS Institute. (2008): SAS User's Guide: Statistics. - SAS Institute Inc., Cary, NC.

[20] Seedor, J. G. (1995): The biophosphanate alendronate (MK-217) inhibit bone loss due to ovariectomy in rats. - Journal of Bone Mineral Research 4: 265-270.

[21] Seedor, J. G., Quarruccio, H. A., Thompson, D. D. (1991): The bisphosphonate alendronate (MK-217) inhibits bone loss due to ovariectomy in rats. - Journal of Bone Mineral Research 6: 339-346.

[22] Thorp, B. H. (1992): Abnormalities in the growth of long bones. - In: Whitehead, C. C (ed.) Bone biology and skeletal disorders in poultry. Proceedings of the 23th Poultry Science Symposium; Abingdon, Illinois. USA. 147-166.

[23] Van Wyhe, R. C., Applegate, T. J., Lilburn, M. S., Karcher, D. M. (2012): A comparison of long bone development in historical and contemporary ducks. - Poultry Science 91: 2858-2865.

[24] Zhang, B., Coon, C. N. (1997): The relations ships of various tibia bone measurements in hens. - Poultry Science 76: 1698-1701.

[25] Ziaie, H., Bashtani, M., Karimi Torshizi, M. A., Naeeimipour, H., Farhangfar, H., Zeinali, A. (2011): Effect of antibiotic and its alternatives on morphometric characteristics, mineral content and bone strength of tibia in Ross broiler chickens. - Global Vetererinary 7: 315-323. 